\title{
Time Management During Corona Virus Era
}

\author{
SAMAN SALEH ${ }^{1}$, ABDULKHALEQ NADER QADER $^{2}$, MOSLEH ZEEBAREE ${ }^{3}$, \\ GORAN YOUSIF ISMAEL ${ }^{4}$, MUSBAH AQEL ${ }^{5}$ \\ ${ }^{1}$ Institute of Graduate Studies and Research, Department of Management Information System, CYPRUS \\ INTERNATIONAL UNIVERSITY, IRAQ, E-mail: 21813094@student.ciu.edu \\ ${ }^{2}$ Business administration department, Shaqlawa technical college, ERBIL POLYTECHNIC UNIVERSITY, IRAQ, \\ E-mail: abdulkhalqnadr@epu.edu.iq \\ ${ }^{3}$ Institute of Graduate Studies and Research, Department of Management Information System, CYPRUS \\ INTERNATIONAL UNIVERSITY, IRAQ, E-mail: 21807157@student.ciu.edu \\ ${ }^{4}$ E-mail: 20185771@std.neu.edu.tr \\ ${ }^{5}$ Institute of Graduate Studies and Research, Department of Management Information System, CYPRUS \\ INTERNATIONAL UNIVERSITY, IRAQ, E-mail: magel@ciu.edu.tr
}

\begin{abstract}
Time management is the ability to plan and control how a person spends his hours in order to achieve his goals effectively. This involves organizing time between different areas of life, from work, household tasks, social life, and hobbies. Time always passes and we cannot control it, but time management is by organizing events in your life in proportion to time. You may often want to get more time in your day, but you only have 24 hours, 1440 minutes, or 86,400 seconds each day. How long can someone invest. Time has acquired its importance for a person, as it represents an important dynamic and mobile dimension in his life that he cannot control, and because it is the vessel that embraces all human interactions and products, and because it is life itself, and that life is the amount of time that a person lives from birth until his death. Therefore, many specialists consider time as the most important component of life, and the most important resource available to human in life, due to his unique and distinctive features.

Because of the importance of time for humans, the ancient civilizations and the various monotheistic religions varied in their interest in it, but during research findings that there are important to recorded a precedent in order to take advantage of each part of time, its parts to implement the righteous and purposeful workers that benefit them with good and benefit in the world and the hereafter, and warned them against wasting it and this is clearly manifested in many of the evidences included in the recommendation and result part.
\end{abstract}

Key words: Corona Virus; Time; Time management; Daily time classification

JEL Classification: J

Received: May 05, 2021

Accepted: June 12, 2021 


\title{
La Gestión del Tiempo en la Era del Virus Corona
}

\author{
SAMAN SALEH ${ }^{1}$, ABDULKHALEQ NADER QADER $^{2}$, MOSLEH ZEEBAREE $^{3}$, \\ GORAN YOUSIF ISMAEL ${ }^{4}$, MUSBAH AQEL ${ }^{5}$ \\ ${ }^{1}$ Institute of Graduate Studies and Research, Department of Management Information System, CYPRUS \\ INTERNATIONAL UNIVERSITY, IRAQ, E-mail: 21813094@student.ciu.edu \\ ${ }^{2}$ Business administration department, Shaqlawa technical college, ERBIL POLYTECHNIC UNIVERSITY, IRAQ, \\ E-mail: abdulkhalqnadr@epu.edu.iq \\ ${ }^{3}$ Institute of Graduate Studies and Research, Department of Management Information System, CYPRUS \\ INTERNATIONAL UNIVERSITY, IRAQ, E-mail: 21807157@student.ciu.edu \\ ${ }^{4}$ E-mail: 20185771@std.neu.edu.tr \\ ${ }^{5}$ Institute of Graduate Studies and Research, Department of Management Information System, CYPRUS \\ INTERNATIONAL UNIVERSITY, IRAQ, E-mail: magel@ciu.edu.tr
}

\begin{abstract}
RESUMEN
La gestión del tiempo es la capacidad de planificar y controlar la forma en que una persona emplea sus horas para alcanzar sus objetivos de forma eficaz. Se trata de organizar el tiempo entre los distintos ámbitos de la vida, desde el trabajo, las tareas domésticas, la vida social y las aficiones. El tiempo siempre pasa y no podemos controlarlo, pero la gestión del tiempo consiste en organizar los acontecimientos de tu vida en proporción al tiempo. A menudo querrás tener más tiempo en tu día, pero sólo tienes 24 horas, 1440 minutos, o 86.400 segundos cada día. Cuánto tiempo puede invertir alguien. El tiempo ha adquirido su importancia para una persona, ya que representa una importante dimensión dinámica y móvil en su vida que no puede controlar, y porque es el recipiente que abarca todas las interacciones y productos humanos, y porque es la vida misma, y esa vida es la cantidad de tiempo que una persona vive desde su nacimiento hasta su muerte. Por ello, muchos especialistas consideran que el tiempo es el componente más importante de la vida, y el recurso más importante del que dispone el ser humano en la vida, debido a sus características únicas y distintivas.

Debido a la importancia del tiempo para el ser humano, las antiguas civilizaciones y las diversas religiones monoteístas variaron en su interés por el mismo, pero durante la investigación se descubrió que es importante registrar un precedente con el fin de aprovechar cada parte del tiempo, sus partes para poner en práctica los trabajadores justos y con propósito que les beneficie con el bien y el beneficio en el mundo y el más allá, y les advirtió que no lo desperdiciaran y esto se manifiesta claramente en muchas de las evidencias incluidas en la parte de recomendaciones y resultados.
\end{abstract}

Palabras claves: Corona Virus; Tiempo; Gestión del tiempo; Clasificación diaria del tiempo

Classificación JEL: J

Recibido: 05 de mayo de 2021

Aceptado: 12 de junio de 2021 


\section{Introduction}

The use of time depends on the skills gained from self-analysis of tasks, planning, evaluation and self-control (Tyunnikov, 2016). Here, a diary must be developed to define priorities and what we want to achieve in every minute and second (Cimatti, 2016). Finding the appropriate strategy in time management depends on both the personality of the individual and their awareness of the importance of time and investment as well as ability on self-stimulation through self-motivation (Abuzid and Abbas, 2016). The level of discipline and self-commitment to perform the tasks(Sudja and Yuesti, 2017).

Time management under this status quo or so-called home quarantine (staying at home) more effectively is done by combining some strategies and daily tasks (Toleikienè et al., 2020). On the social side, for example, family activities can be intensified through. Meeting on food. Do homework and fix what can be fixed. Arrange a specific time plan to bring about a beneficial change to the home (Epstein et al., 2018). Caring for children, setting their times, finding ways and activities that motivate them to learn and enjoy building in the field of using e-learning in educational, scientific and research activities and investing in free opportunities launched by most universities and research centers in learning, education, or active participation in it (Kontovourki et al., 2017).

\section{Aim of the study}

The importance of this study is highlighted by the importance of the limitations of the topic of spraying on how to manage time in the Coronavirus crisis. As a result of the current crisis in terms of isolation and quarantine, and the cessation of all fields of life, such as schools, universities, government institutions and private sector organizations, so the study aims to identify the most important aspects of determining time management and contribute to realizing the reality as a result of this crisis for the sake of the sustainability of life.

\section{Research methodology}

This research will be conducted based on an integrative review methodology where relevant articles will be used depending on the scope of exploration with keywords such as Coronavirus, time, time management, and daily time classification. An integrative review methodology is a special procedure that drafts relevant papers over an extended period of time for review in other areas to provide a better understanding of the topic of discussion.

\section{Literature Review}

Time passes in the time of the third millennium. The time light flashes quickly, as a result of the crowding out of businesses, works, events, etc., but in the time of Corona, those who work remotely also prepare themselves for this through the digital economy system (Forsythe et al., 2020).

In the time of Corona, (Donthu and Gustafsson, 2020) some of them walk like a turtle to those who are tired of sitting at home as a result of being unemployed or not having the skills of the times; And some are in the normal position is not enough today and he hopes more - and those are the producers and the accomplished - so the need and necessity for time management to increase productivity and giving between events and important and urgent actions come; [( Waller et al., 2020)In the time of Corona for such human producers there is a need for more efficient time management.

Hacker, (2019) Pointed out that an economics person's time means money, productivity, competitiveness and giving. Its value is important and its loss is a loss. Unfortunately, most of us set this time to the lowest possible and what is required by the employer. Hyder, (2020) Mentioned that In the time of Corona, economic growth and the knowledge economy became very important; Also, (Marks, 2019) productivity and the spirit of giving are required to compensate for the losses in the slower growth and its affiliation with the global economic file. 
Palma, (2019) argued that the socialite's human time that determines and strengthens human relations, but as a result of their abundance in our country requires their identification or abbreviation, otherwise they consume our day, and this is really what happens with most people. The time of the Corona pandemic is the perfect time to frame our social occasions, whether in our wedding, wedding or even communication and mechanisms remotely (Murray, 2020).

Becker et al., (2019) pointed out that the time of a person to rest and sleep is an important moment, otherwise he will lose his compass and lose himself and forget it because health is the height of the hump of life, (Palma, 2019) and there are limits to rest and sleep according to the age of the person and his health condition; And in the time of Corona some people were overburdened by the sleep agent However, the sleep scale has decreased so much for remote workers that they have no time to rest at all; But I did not sleep long and did not shorten the ages throughout the night(Becker et al., (2019).

Horton, (2020) declared that person's time to work must be exploited beneficially, because sincerity in work without wasting time is the basis for permissible livelihood, and sincerity with work also devotes to the comfort of conscience, guilt of mind, complacency and enhances belonging; In the time of Corona, work efficiency, the productivity index, and flexible work have become important measures for the purpose of each one of us being a "loyal" and not a "brain of the thief" who stole the institutions time.

Fieldhouse, (2013) mentioned that person's time for sport, culture, and education may be considered by some to be secondary or perfect, but it is the basis of a healthy mind system in a healthy body, and the balance between them is a necessity for the purposes of maintaining health and reason; At the time of the Corona pandemic, exercise became essential to fighting weight and overload as a result of sitting on the sofa for those who did not work or sitting on chairs for those who worked remotely.

Murthy, (2020) pointed out that human time for the rest of the other things is important and varied. Education, meditation, communication, reading, mobility, love, feeling and other things are necessary, but without excess or neglect; At the time of the Corona pandemic, reading, writing, meditation, faith, and social communication from a distance, and all others became important because life during Corona was not the same as before; To what extent!

\section{Time management is an art or science}

There is a science that does not go into the school curricula, and the person does not acquire it through advice, and this science does not have major general molds, because it is closer to art, and it is an art because it is very attached to the individual, it is an individual and not collective action, and the human touches and his imprint are clearly visible in his life as a result of his dealings(Al-Zoubi, 2016) With this art, this science is related to the organization of time, but it becomes an art when it is talked about in the means and mechanisms, and it becomes the art of time management. This art differs from crisis management, as the crisis is often collective, but if it is individual, time or time scheduling becomes a major factor in dealing with the crisis, and many say: The accumulation of unorganized time turns into a real crisis; you need more than one element to solve or deal with it (Wigger and Buch-Hansen, 2014).

The art of time management is a broad and general term. It includes the whole of human life, his personal and practical life, his emotional and material life, and insofar as a person sets boundaries between these patterns of life, he achieves success, and avoids chaos, confusion and accumulation (Arteconi et al., 2012).

This is in the general theory, but if we are close to allocating, then talking about the art of time management is gaining importance in times of crisis, i.e. one is expected to manage his time in a crisis experienced by all[Arteconi et al., 2012], and this management may be on Perhaps people all over the world live in a crisis at the present time, the Corona pandemic crisis, and it is divided into two parts, a section related to the scientific fissure of the crisis, disease, vaccine, epidemic, 
prevention, and a section related to time fracture, that is, time management with the presence of the first crisis(Al-Zoubi, 2016). Under these circumstances, and at a time when people are required not to go to their jobs, works, schools, and universities, but not to roam and stay at home, the space of time becomes suddenly available to the point where a person cannot absorb it quickly(Duguid, 2012), especially if he cannot work from The house, and here lies the problem, which also includes the man who works from home, and we all know the difference between sitting at home behind the desk, or sitting in the workplace behind the office, in the first an automatic relaxation, and in the second a constant alert, readiness and motivation (Al-Zoubi, 2016).

The first thing that we must do is to set a daily plan and implement it as possible without inaction, and it must take into account the presence of other people in the house, wife, children and perhaps a nanny, and in many cases everyone should agree on this plan, which is a family plan, and after Agreeing to it, each family member must develop their own plan, which includes both young and old of the most difficult types of departments (Sinha et al., 2020). The most important element of this plan relates to television, and for this reason not to follow the news around the clock will be the first important measure in the family or individual plan, and watching the news is a strange habit with distinction (Vanapalli et al., 2020). Or a catastrophe or general epidemic occurred, and he sits in front of the TV knowing that he is unable to do anything, as he has no role in changing the direction of events, and what is a political or medical analyst for example, and no one asks him to write a report on war, crisis, or The epidemic, for this first time management should be to organize watching newscasts, once or twice a day, and distribute the remaining views to other things, although I prefer dealing with television as if you were at work (Kotfis et al., 2020).

The second element, the complete readiness to dialogue with the other, and the Corona crisis has proven that many families are beginning to get to know each other again, and here either the problems increase or decrease according to the method, in short, it is nice to rediscover those we live with (Vanapalli et al., 2020).

If the two elements, the family and individual plan, and prepare for dialogue through psychological preparation are available, then we have come a long way (Kotfis et al., 2020), in managing time, and here we talked about personal and not practical time, because an important part of time is supposed to be devoted to carrying out the tasks. And the conversation is brutal about the stories of rediscovering others.

\section{What is corona disease?}

Corona Disease Corona or corona virus is one of the viruses that affect the respiratory system or digestive tract in mammals, and this name was called because of the bumps on its surface that resemble the crown (Oscanoa et al., 2020). This virus was isolated for the first time in 1937, as it caused infectious inflammation of the airways of birds. Corona virus that affects humans of type OC43 and $229 \mathrm{E}$ constitutes about $30 \%$ of cases of cold and cold, and the virus that infects humans was isolated for the first time in the 1960s, and several types of corona virus appeared, some of which are considered dangerous, and it is indicated that the virus Wuhan or the new Corona Virus 2019 is its latest variant to date (Zhang et al., 2020).

\subsection{Corona virus symptoms}

Symptoms similar to cold or flu symptoms occur two to four days after infection with the Coronavirus, and these symptoms are generally mild, and these include the following Sneezing ( Runny Nose, Fatigue, Cough Fever, Pneumonia, Kidney Failure), as well as they have caused Some people with respiratory syndrome in; As three to four people out of every ten people affected have died, but most of them have other health problems, and this confirms what has been shown by current studies in this field (Yin et al., 2020), as studies have shown that people with weak immunity and people who suffer from simultaneous health problems Being with the virus such as diabetes, 
cancer, chronic heart disease and chronic lung disease were more likely to be infected with the Coronavirus, and more likely to have severe symptoms of the disease(Nobel et al., 2020).

\subsection{Methods to prevent transmission of the coronavirus}

The transmission of the virus can be prevented by taking daily preventive measures that prevent the transmission of all respiratory-related diseases. Also, it should be noted that if a person with respiratory syndrome is treated within fourteen days of his infection without taking the recommended preventive measures, the doctor should be consulted to assess the situation (Cortes and Zuñiga, 2020). Among the recommended measures to prevent respiratory diseases are the following: Washing the hands with soap and water for twenty seconds, and using sterile alcoholic materials in case water and soap are not available. And teach children that too. Cover your nose and mouth with tissue when you sneeze or cough, and dispose of them directly. Not to touch the eyes, nose, or mouth with unwashed hands. Avoid sharing cups and utensils with the affected person. Avoid welcoming people with kissing. Maintain cleaning and sterilizing surfaces and tools that are used and touched as frequently as door handles (Maqbool and Khan, 2020).

\subsection{Corona virus treatment}

Although there is no cure for disease conditions resulting from infection with the Corona virus so far, there are some measures and procedures that can be followed in the event of infection with the Corona virus, including the following: Taking a sufficient rest. Drink enough water. Avoid smoking, and avoid being in areas full of smoke. Use humidifiers and cool mist evaporators, after making sure that they are clean (Cascella et al., 2020).

The first case of infection occurred in Jordan in April 2012, and it was registered for the first time by health sector officials in September 2012 in the Kingdom of Saudi Arabia, where most of the cases of this syndrome were related to travel or residence in countries of the Arabian Peninsula or surrounding areas. In most cases, the incubation period for the disease - the time between exposure to the disease and the onset of symptoms - ranges from five to six days, but in some cases it may also range from two to twelve days (Mostafa et al., 2020). Symptoms Respiratory Syndrome and its complications may show some symptoms for people with respiratory syndrome, and symptoms can be divided into respiratory and digestive symptoms as follows: Respiratory symptoms: People with respiratory syndrome often suffer from severe respiratory symptoms, including: fever, cough, distress Breathing (Lechowicz et al., 2020).

\subsection{Corona Virus as:"Lost time exam"}

Since the declaration of the state of emergency in March, we have been concerned about how we manage time, during our home quarantine. We read a lot about it, seek sample opinions from virtual and real friends, and analyze some phenomena related to the consequences of losing time within about three months of the closure of educational institutions, the irregularity of most sectors, and the disruption of public, private and private institutions. It is evident that time is the backbone of life, and its importance stems from the fact that it is the engine of production and work, and in it we calculate the value of everything, perhaps the most prominent of which are ages, years of study, hours of work, wage schedules, debt scheduling, and country loss (Zeebaree et al.,2020).

The question most in need appears to be the answer: How will most of us recover from the "aftershocks" of the long void, and to waste long hours without a goal? Children and young people, for example, found in the crisis an opportunity to penetrate into electronic games, mortgaged themselves for them, for late nights and sleep until midday, and not planning any beneficial activity for the next day, and in our surroundings, especially the bobgy game (shaikh et al 2021)

In your turn, you can stand up to the distance education initiative, launched by the Ministry of Education in the region, by providing a website for the purpose of helping students review their curricula through the e-learning portal or distance education, as well as the adoption by many 
universities of direct e-learning programs and registered lessons. Especially after hearing decisions about the imminent return to schools and automatic upgrade. The irony is that not all students were eager to learn a new foreign language in the crisis, or to read books outside their curricula, and preferred to proceed with "goal-free time" without aim.

Virtual space and social media platforms are a free opportunity to learn about the repercussions of the coup lack of time value in life (Zeebaree et al.,2020), the times of sleep and waking have changed, interests changed, and activities for the majority of them either learn cooking arts, or follow pandemic news, some return to the land and take care of the home garden, or Individual wandering in the mountains, and a little e-learning, which we did not manage well, and we failed to transform it into a community-based education in which all family members participate, in which knowledge is circulated, building on it is encouraged, and an active brain is kept out of inactivity, or thinking about something.

It must be recognized that we failed to test the time in the time of "Covid 19", and we were unable to transform long periods of emptiness to rediscover ourselves, our families, our homes, our land, our gardens, and our surrounding nature, and we spent most of the time either in actual sleep or inactivity (Nicola et al., 2020).

The difficult time test does not apply to some classes, such as workers, merchants, and farmers, but most groups were unable to manage it, and they did not succeed in turning it into something positive (shahzad et al 2017).

It is a joy to start returning to the land and launch projects to develop home gardens, but that pleasure will not be complete, except with sound management of time, setting a program to recover from emptiness and inactivity, and get rid of the culture of consumption (Kirigia and Muthuri, 2020).

It was possible to return to the self during the crisis, learn new skills in self-sufficiency and home management, stop the current consumption pattern, invest time in work and physical activity in the home garden if any, or plant on porches and roofs, and learn new manual skills, the crisis revealed our need for it Returning to reading, a habit that has become rare in our lives, Because it is the strength, the nucleus of life.

Here comes the role of scientific, social and psychological research, so the consequences of long time can be tracked from non-work in terms of consumption patterns, late sleeping times disturbed eating times, expected obesity, excessive addiction to electronic games, anxiety((Zeebaree et al.,2020), psychological effects of income sources damage, and permanent tension recoils from a crisis Most countries of the world have taken hold of them, and we do not know how long we will go in their tunnels? How will the world look after it? And most importantly; What harsh lessons have we learned from them?

\section{Conclusion}

Societies have changed their view of the issue of time and its management in the last five decades of the last century as it has become the international standard and indicator for judging the success or failure of different countries and institutions in achieving their desired goals, plans and programs. The developed countries, societies and institutions adopt the topic of time and its management as one of the important strategic issues and put it at the top of its priorities in order to increase the level of its progress, due to its association with various sciences, its interference in all its operations and its penetration into all parts of its various stages and through this research we have reviewed the most important patterns, aspects and tasks of time management In light of crises, especially what the entire world faces, which is the domestic stone in the era of what we call it, the era of crises and the stopping of industry, trade, movement, land, air, and sea transportation, and voluntary and obligatory stay in homes, and what we call now is the era of stopping or the era of Corona, and through our research we commend the importance of time management, organization and division between tasks All, especially economic, social and domestic, and to determine the hours of sleep and work. 
It is required to organize and exploit time because we will be held accountable for it on the Day of Resurrection and the lost time is a crime against the human being that leads to remorse and we must use it with benefit, and we must stay away from the waste of time that everyone knows; Inevitably, during the Corona pandemic, time passes like a sword for workers and a turtle for retirees or losers.

Finally; People these days live in a crisis of time and its management despite the tools of technology that approximate distances, but the multitude and diversity of works necessitates us to make fundamental changes in our social system for the purposes of optimizing the use of time, for time is like a sword if you do not cut it with benefit, it cuts you with sorrow and remorse! The matter added to the importance of the Corona pandemic, so that time would be short for diamonds for remote workers.

The spread of Corona virus in dozens of countries of the world and its declaration of a "global pandemic" led to taking precautionary decisions and measures to prevent the infection of the people of those countries with the expanding virus from one place to another.

The virus has caused authorities in most countries of the world to disable schools and universities in order to prevent its spread, as there are millions of students, and the possibility of infection is very strong.

And so did many international companies. Like Facebook and Twitter, they move their employees 'work home to protect them from infection with the virus that is running the whole world.

Likewise, with the authorities taking a quarantine against him because of his infection with the Coronavirus, and preventing him from communicating with his surroundings, he sits long hours every day without doing anything, especially since most of the infected cases do not suffer from the disease significantly (Suhaim et al 2018).

Such decisions cause the wheel of life to stop in many countries, and hundreds of millions sit in their homes, despite the approaching spring weather in many of them, which are often used for walks after a long winter season, which leads some to search for useful activities that they can do on a daily basis as a fraction for boredom and to buy time.

\section{Results and recommendation}

In order to organize time in light of the Corona crisis, depending on what we mentioned above, we draw the following results, as the best method that contributes to organizing time in light of the Corona crisis

\subsection{Do what is useful}

Since millions will not work from their homes, but will be on semi-open leave, but without many external activities, it makes sense to invest their time in what is beneficial and productive (the quarantine person can do most of it without sharing them).

After you take all precautions to protect yourself and your family from the transmission of the virus to you; By raising the level of hygiene to the highest level, with the need to wash hands with soap periodically, and to use sterilizers, and to avoid handshaking and kissing, and to reduce visits except those necessary, you can start the holiday with what is fruitful on the personal side.

\subsection{Don't be busy browsing, train}

Do not occupy most of your time on social media, as most of the news are mostly incorrect, but set aside a specific time, while trying to register for the majority courses for free, where you can learn in many courses and workshops and only need a laptop or even a mobile phone. 


\subsection{Read with fun}

And if you do not want that for some reason, reading and reading can make you free from a lot of boredom and wasting time, if you have been forbidden for outdoors, if there is an overcrowded garden near your home, you can go to it without touching the existing chairs, and take a paper book with you if you have arranged Your own library, and if you do not find there are multiple applications and sites for books that you can easily access, most of them are free and some of them are very small numbers.

Perhaps the most beautiful thing in leisure time is to be with a useful and enjoyable book at the same time, such as that which talks about the nature of man or his behaviors related to psychology and achievements, and if you do not prefer this kind then you should have literature, poetry, art of novel and story where there are many.

A family member can read a book, and then exchange discussion and dialogue with each other about its content and ideas, as well as parents can read the stories and narrations of their children.

\subsection{Choose carefully}

And if you are not a fan of learning and reading and are only looking for entertainment and perhaps watching your movies or series fill your time, and there are of course tens of thousands of movies and series that are distributed on sites and applications, most of which are free too.

You can use these views to improve your foreign language, but choose a meaningful movie, or tell a resume where these films are more documentary, dramatic than fictional.

\subsection{Do not relax for long}

Sitting at home is good and safe with the spread of corona, but with a feeling of constant hunger and eating many foods without movement, you should organize your movements so that your body stays without obesity changes close by. You have to do sports daily and sporadically.

\subsection{Have a positive habit}

If you like the experience, you can choose for yourself a new daily habit for certain minutes that you can change something of your life through; Such as "writing a diary or highlighting what is happening with you. Worshiping like doing the night. Making a plan for the whole day and implementing it from home. Think for a certain period."

\subsection{Don't forget to communicate}

Sitting at home in order to get away from crowding, but that does not mean isolation from others, especially the people of the house, allocate a daily time for them to nip Connection.

It is important that you do not neglect your lessons and duties. Because time will pass quickly, if there are many obligations on you, it will end and then go to activities

\section{References}

1. Abuzid, H. F. T., \& Abbas, M. (2016). Role of self-efficacy beliefs and its relationship with emotional intelligence to developing leadership capabilities. International Journal of Applied Business and Economic Research, 14(3), 1975-1989.

2. Al-Zoubi, M. (2016). The Effect of the Time Management Art on Academic Achievement among High School Students in Jordan. Journal of Education and Practice, 7(5), 158-167.

3. Al-Zoubi, M. (2016). The Effect of the Time Management Art on Academic Achievement among High School Students in Jordan. Journal of Education and Practice, 7(5), 158-167. 
4. Arteconi, A., Hewitt, N. J., \& Polonara, F. (2012). State of the art of thermal storage for demandside management. Applied Energy, 93, 371-389.

5. Becker, S. P., Epstein, J. N., Tamm, L., Tilford, A. A., Tischner, C. M., Isaacson, P. A., ... \& Beebe, D. W. (2019). Shortened sleep duration causes sleepiness, inattention, and oppositionality in adolescents with attention-deficit/hyperactivity disorder: Findings from a crossover sleep restriction/extension study. Journal of the American Academy of Child \& Adolescent Psychiatry, 58(4), 433-442.

6. Cascella, M., Rajnik, M., Cuomo, A., Dulebohn, S. C., \& Di Napoli, R. (2020). Features, evaluation and treatment coronavirus (COVID-19). In Statpearls [internet]. StatPearls Publishing.

7. Cimatti, B. (2016). Definition, development, assessment of soft skills and their role for the quality of organizations and enterprises. International Journal for quality research, 10(1).

8. Cortes, A. A., \& Zuñiga, J. M. (2020). The use of copper to help prevent transmission of SARSCoronavirus and Influenza viruses. A general Review. Diagnostic Microbiology and Infectious Disease, 115176.

9. Donthu, N., \& Gustafsson, A. (2020). Effects of COVID-19 on business and research. Journal of business research, 117, 284.

10.Duguid, P. (2012). 'The art of knowing': social and tacit dimensions of knowledge and the limits of the community of practice. In The Knowledge Economy and Lifelong Learning (pp. 147-162). Brill Sense.

11.Epstein, J. L., Sanders, M. G., Sheldon, S. B., Simon, B. S., Salinas, K. C., Jansorn, N. R., ... \& Hutchins, D. J. (2018). School, family, and community partnerships: Your handbook for action. Corwin Press.

12.Fieldhouse, P. (2013). Food and nutrition: customs and culture. Springer.

13.Forsythe, E., Kahn, L. B., Lange, F., \& Wiczer, D. (2020). Labor demand in the time of COVID-19: Evidence from vacancy postings and UI claims. Journal of public economics, 189, 104238.

14. Hacker, J. S. (2019). The great risk shift: The new economic insecurity and the decline of the American dream. Oxford University Press.

15. Horton, R. (2020). The COVID-19 Catastrophe: What's Gone Wrong and How to Stop It Happening Again. John Wiley \& Sons.

16.Hyder, A. (2020). SHORT NOTES ON THE ECONOMY DURING THE COVID-19 CRISIS.

17.Kirigia, J. M., \& Muthuri, R. N. D. K. (2020). The fiscal value of human lives lost from coronavirus disease (COVID-19) in China. BMC research notes, 13, 1-5.

18. Kontovourki, S., Garoufallou, E., Ivarsson, L., Klein, M., Korkeamaki, R. L., Koutsomiha, D., ... \& Virkus, S. (2017). Digital Literacy in the Early Years: Practices in Formal Settings, Teacher Education, and the Role of Informal Learning Spaces.

19.Kotfis, K., Williams Roberson, S., Wilson, J. E., Dabrowski, W., Pun, B. T., \& Ely, E. W. (2020). COVID-19: ICU delirium management during SARS-CoV-2 pandemic. Critical care, 24, 1-9.

20.Lechowicz, K., Drożdżal, S., Machaj, F., Rosik, J., Szostak, B., Zegan-Barańska, M., ... \& Kotfis, K. (2020). COVID-19: the potential treatment of pulmonary fibrosis associated with SARS-CoV-2 infection. Journal of clinical medicine, 9(6), 1917.

21.Maqbool, A., \& Khan, N. Z. (2020). Analyzing barriers for implementation of public health and social measures to prevent the transmission of COVID-19 disease using DEMATEL method. Diabetes \& Metabolic Syndrome: Clinical Research \& Reviews, 14(5), 887-892.

22. Marks, D. (2019). Common challenges of smallholders in ASEAN: Lacking access to land, water, market, and state. In Water and Power (pp. 253-281). Springer, Cham.

23.Mostafa, A., Kandeil, A., Shehata, M., Shesheny, R. E., Samy, A. M., Kayali, G., \& Ali, M. A. (2020). Middle east respiratory syndrome coronavirus (mers-cov): State of the science. Microorganisms, 8(7), 991.

24.Murray, E. J. (2020). Epidemiology's Time of Need: COVID-19 Calls for Epidemic-Related Economics. Journal of Economic Perspectives, 34(4), 105-20.

25. Murthy, R. S. (2020). COVID-19 pandemic and emotional health: Social psychiatry perspective. Indian Journal of Social Psychiatry, 36(5), 24. 
26.Nicola, M., Alsafi, Z., Sohrabi, C., Kerwan, A., Al-Jabir, A., losifidis, C., ... \& Agha, R. (2020). The socio-economic implications of the coronavirus pandemic (COVID-19): A review. International journal of surgery (London, England), 78, 185.

27.Nobel, Y. R., Phipps, M., Zucker, J., Lebwohl, B., Wang, T. C., Sobieszczyk, M. E., \& Freedberg, D. E. (2020). Gastrointestinal symptoms and coronavirus disease 2019: a case-control study from the United States. Gastroenterology, 159(1), 373-375.

28.Oscanoa, T. J., Romero-Ortuno, R., Carvajal, A., \& Savarino, A. (2020). A pharmacological perspective of chloroquine in SARS-CoV-2 infection: An old drug for the fight against a new coronavirus?. International journal of antimicrobial agents, 56(3), 106078.

29.Palma, J. G. (2019). Behind the Seven Veils of Inequality. What if it's all about the Struggle within just One Half of the Population over just One Half of the National Income?. Development and Change, 50(5), 1133-1213.

30.Shahzad, B., Abdullatif, A. M., Saleem, K., \& Jameel, W. (2017). Socio-Technical Challenges and Mitigation Guidelines in Developing Mobile Healthcare Applications. Journal of Medical Imaging and Health Informatics, 7(3), 704-712.

31.Sinha, M., Pande, B., \& Sinha, R. (2020). Impact of COVID-19 lockdown on sleep-wake schedule and associated lifestyle related behavior: A national survey. Journal of Public Health Research, 9(3).

32.Shaikh, A., AlReshan, M. S., Asiri, Y., Sulaiman, A., \& Alshahrani, H. (2021). Tele-COVID: A Telemedicine SOA-Based Architectural Design for COVID-19 Patients. CMC-COMPUTERS MATERIALS \& CONTINUA, 67(1), 549-576.

33.Sudja, I. N., \& Yuesti, A. (2017). The Influences of Education and Training, Leadership, Work Environment, Teacher Certification on Discipline and Teacher's Professionality in High School at Bali Province. Scientific Research Journal (SCIRJ), 5(9).

34.Suhaim, M. A., Alrizq, M. S., \& Almalki, M. A. (2018). An Effective Baby Temperature Monitoring System. International Journal of Computer Science and Information Security (IJCSIS), 16(12).

35.Toleikienè, R., Rybnikova, I., \& Juknevičienè, V. (2020). Whether and how does the Crisis-Induced Situation Change e-Leadership in the Public Sector? Evidence from Lithuanian Public Administration. Transylvanian Review of Administrative Sciences, 16(SI), 149-166.

36.Tyunnikov, Y. S. (2016). Interrelation of Evaluation and Self-Evaluation in the Diagnostic Procedures to Assess Teachers' Readiness for Innovation. European journal of contemporary education, 16(2), 248-256.

37.Vanapalli, K. R., Sharma, H. B., Ranjan, V. P., Samal, B., Bhattacharya, J., Dubey, B. K., \& Goel, S. (2020). Challenges and strategies for effective plastic waste management during and post COVID19 pandemic. Science of The Total Environment, 750, 141514.

38.Waller, G., Pugh, M., Mulkens, S., Moore, E., Mountford, V. A., Carter, J., ... \& Farrell, N. R. (2020). Cognitive-behavioral therapy in the time of coronavirus: Clinician tips for working with eating disorders via telehealth when face-to-face meetings are not possible. International Journal of Eating Disorders.

39.Wigger, A., \& Buch-Hansen, H. (2014). Explaining (missing) regulatory paradigm shifts: EU competition regulation in times of economic crisis. New Political Economy, 19(1), 113-137.

40.Yin, R., Feng, W., Wang, T., Chen, G., Wu, T., Chen, D., ... \& Xiang, D. (2020). Concomitant neurological symptoms observed in a patient diagnosed with coronavirus disease 2019. Journal of medical virology.

41.Zeebaree, M., Sattar, S., \& Shukri, N. (2020). Innovative Technologies Impact on Socio-economic, Health, and Educational Activities during COVID-19 Era. Prensa Med Argent S, 3, 2-7.

42.Zhang, D., Ma, Z., Chen, H., Lu, Y., \& Chen, X. (2020). Valinomycin as a potential antiviral agent against coronaviruses: a review. Biomedical journal. 